\title{
ALLELOPATHIC EFFECT OF Brassica ON WEED CONTROL AND YIELD OF WHEAT
}

\author{
P. K. Biswas, M. M. Morshed, M. J. Ullah and I. J. Irin \\ Dept. of Agronomy, Sher-e-Bangla Agricultural University, Dhaka \\ Corresponding author: parimalbiswas@hotmail.com
}

Key words: Allelopathy, weed control, rapeseed/mustard, wheat

\begin{abstract}
The experiment was conducted at the Agronomy farm of Sher-e-Bangla Agricultural University to identify the allelopathic effect of Brassica species along with their incorporation methods to control weeds in wheat field. The experiment was assigned in a split-plot design where three cultivated Brassica spp. were in the main plot and five different ways of green Brassica biomass inclusion were in the sub-plot. Brassica crops were uprooted at 30 days after sowing (DAS) and incorporated to the soil @ $0.5 \mathrm{~kg} \mathrm{~m}^{-2}$ as per treatment. Wheat seeds were sown on December 04, 2007 using $20 \mathrm{~cm}$ line to line distance. Weeds e.g., Amaranthus spinosus, A. viridis, Lindernia procumbens, Heliotropium indicum, Polygonum hydropiper, Celosis argentina, Ageratum conyzoides, Brassica kaber and Digitaria ischaemum were not found in the wheat field. Significantly the highest weed dry matter $\left(1.72 \mathrm{~g} \mathrm{~m}^{-2}\right)$ was found in Brassica juncea plots at 30 DAS but in Brassica napus field $\left(1.44 \mathrm{~g} \mathrm{~m}^{-2}\right)$ at 50 DAS. The lowest weed dry matter at 30 DAS $\left(0.89 \mathrm{~g} \mathrm{~m}^{-2}\right)$ was recorded with total incorporation of Brassica biomass to the soil but $50 \%$ incorporation and 50\% spreading at 50 DAS. The Brassica biomass spreading above ground, mixed with soil and 50\% spreading + 50\% mixed with soil resulted positively compared to other ways of biomass incorporation. The highest grain yield $\left(3.83 \mathrm{t} \mathrm{ha}^{-1}\right)$ of wheat was given by Brassica juncea when spreaded on the above ground soil.
\end{abstract}

\section{Introduction}

Wheat (Triticum aestivum L.) is the most important cereal crop in the world as well as in Bangladesh that provides about $20 \%$ of total food calories. Weed is the natural enemy of wheat that reduces its yield if not properly controlled. The yield reduction of wheat by weed is reported to be 20 - 30\% (Turk and Tawaha, 2002) and $150 \%$ by Peterson (1965). Some crops are specially useful because they have the ability to suppress other plants that attempt to grow around to them.

Allelopathy refers to a plant's ability to chemically inhibit the growth of other plants. Rapeseed and Mustard are reported the most useful allelopathic cover crop that reduced total weed biomass in soybean by 40 - 49\% (Krishnan et al., 1998). Weed suppression is effective when crop residues left undisturbed on the soil surface but the effect is lost when tilled into the soil (Sheila, 1986). Putnam et al. (1983) reported that weeds that were reduced by rye mulch included ragweed $(43 \%)$, pigweed (95\%) and common purslane (100\%). Worsham (1991) and Schilling et al. (1986) reported 68-80\% reduction of broadleaf weeds by rye. Yenish and Worsham (1993) also reported highest weed control by rye application. Anon. (1993) reported allelopathic effect of rapeseed and showed 90\% reduction of yellow nutsedge on sweet potatoes. Boydston and Hang (1995) reported that all members of the mustard family (Brassicaceae) contain mustard oils that inhibit plant growth and seed germination. The concentration of allelopathic mustard oils varies with species and variety of mustard. Sullivan (2003) reported that crop residues when left on the soil surface, can be expected to reduce weed emergence by 75 to $90 \%$ and when decomposed, weed suppression effect also declined. An attempt was therefore, undertaken to study the allelopathic effect of Rapeseed and Mustard in controlling weeds in Wheat. 
Biswas et al.

\section{Materials and Methods}

The experiment was conducted at the Agronomy farm of Sher-e-Bangla Agricultural University, Dhaka1207, during the period from November 2007 to March 2008 in a silty clay loam soil having low organic matter (0.82\%) and slightly acidic soil ( $\mathrm{pH}$ 5.47-5.63). Three Brassica varieties one from campestris (BARI Sarisha-15), one from juncea (BARI Sarisha-11) and the other from napus (BARI Sarisha-13) species were sown on November 02, 2007. The crop was fertilized with 180-100-180-60-10-5 kgha ${ }^{-1}$ of urea, TSP, MoP, Gypsum, Boric acid and Zinc oxide, respectively of which half of urea and the full amount of other fertilizers applied as basal dose. As the crops were uprooted, no additional urea fertilizer was applied. Weeding, mulching and thinning were done at 20 DAS (days after seeding). The Brassica crop was uprooted at 30 DAS and the land was then ploughed and cross ploughed, leveled and fertilized as per recommendation of wheat. The experiment was laid out in split-plot design with three replications. Three Brassica species was assigned in the main plot and six different ways of biomass incorporation (No biomass application, biomass spreading above the ground, biomass mixed with soil, biomass spreading in lines and $50 \%$ biomass as spreading $+50 \%$ biomass as mixed with soil) in the sub plot. The wheat variety Shatabdi (BARI Gom21) was sown on 04 December, 2007 maintaining $20 \mathrm{~cm}$ line distance. One third urea and the full amount of other fertilizers were applied as basal and the rest urea in two equal splits at CRI stage and before flowering stage. All the intercultural operations were done as and when necessary. Weed data was recorded on 30 and 50 DAS. The yield and other data were recorded using standard procedure. The collected data were analyzed and the mean differences evaluated by least significant difference test (LSD).

\section{Results and Discussion}

\section{Weed Species}

Twelve weed species belongs to 7 families were found infested in the experimental field of which Cyperous rotundus, Cynodon dactylon, Eleusine indica, Digitaria sanguinalis, Chenopodium album were found with major population whereas 9 weeds had been found unavailable in wheat field but available to the surrounding areas. The name and family of the weeds are shown in Table 1 . The results showed that Brassica biomass had allelopathic effect to suppress some weed species in wheat field. Anon. (1993) also reported the suppressive nature of rapeseed to control weeds in sweet potatoes.

\section{Weed density and weight}

Inclusion of different Brassica biomass had no significant variations on weed population in wheat field at 30 and 50 DAS but the methods of biomass incorporation resulted significant differences of weed population at 30 DAS though no variation was observed at 50 DAS (Table 2). The lowest number of weed population (15.33 $\mathrm{m}^{-2}$ ) was found in $\mathrm{B}_{4}$ (spreading in lines) that was similar to $\mathrm{B}_{2}$ (Spreading above ground) and $\mathrm{B}_{5}(50 \%$ spreading $+50 \%$ mixed with soil). Sullivan (2003) reported the highest suppressive effect of crop residues when left on the surface than decomposed to the soil. Uremis et al. (2009) reported the allelopathic potential of residues of some brassica species suppressed johnsongrass. The result was also in agreement with the findings of Boydston (2008) who reported that Brassicaceae cover crops suppress weeds due to allelopathic substances released during degradation of the cover crop residues.

Table 1. Local name, common name, scientific name, and family of weeds unavailable in Brassica biomass treated plots

\begin{tabular}{c|c|c|c}
\hline Local name & Common name & Scientific name & Family \\
\hline \multicolumn{2}{l}{ Weeds available in the experimental plot } & & \\
Mutha & Nut sedge & Cyperus rotundus & Cyperaceae \\
Chapra & Goose grass & Eleusine indica & Gramineae
\end{tabular}


Allelopathic Effect of Brassica on Wheat

\begin{tabular}{ccccc}
\hline Local name & Common name & Scientific name & Family \\
\hline Durba & Bermuda grass & Cynodon dactylon & Gramineae \\
Anguli ghas & Scrab grass & Digitaria sanguinalis & Gramineae \\
Bon mosur & Wild lentil & Vicia stiva & Leguminosae \\
Choto shama & Jungle rice & Echinochloa colonum & Gramineae \\
Bathua & Lambsquarter & Chenopodium album & Chenopodiaceae \\
Tita begun & Tita begun & Solanum torvum & Solanaceae \\
Chatidhara & Flat cyperus & Cyperus compresus & Cyperaceae \\
Shetodron & Leucas & Leucas aspera & Labiatae \\
Malancha & Alligator weed & Alternanthera philoxeroides & Amaranthaceae \\
Bon china & Torpado grass & Panicum repens & Gramineae \\
Weeds unavailable in the experimental plot but available to the adjacent area & \\
Khet papri & Khet papri & Lindernia procumbens & Scrophulariaceae \\
Hati shur & Wild heliotrop & Heliotropium indicum & Boraginaceae \\
Kata notae & Spiny pig weed & Amaranthus spinosus & Amaranthaceae \\
Shak notae & Pig weed & Amaranthus viridis & Amaranthaceae \\
Bish katali & Smart weed & Polygonum hydropiper & Polygonaceae \\
Shet morog & White cock's comb & Celosia argentina & Amaranthaceae \\
Chagla gacha & Goat weed & Ageratum conyzoides & Compositae \\
Bon sarisha & Wild mustard & Brassica kaber & Cruciferae \\
Choto anguli & Smooth scrab grass & Digitaria ishchamaemum & Gramineae \\
\hline
\end{tabular}

The highest weed dry weight $\left(1.72 \mathrm{~g} \mathrm{~m}^{-2}\right)$ was recorded in juncea plots as compared to Brassica campestris $\left(1.16 \mathrm{~g} \mathrm{~m}^{-2}\right)$ and Brassica napus $\left(1.16 \mathrm{~g} \mathrm{~m}^{-2}\right)$ at 30 DAS but at 50 DAS Brassica napus treated plots showed the highest weed dry weight $\left(1.44 \mathrm{~g} \mathrm{~m}^{-2}\right)$ and the Brassica juncea showed the lowest weed dry weight $\left(0.96 \mathrm{~g} \mathrm{~m}^{-2}\right)$ that was similar to Brassica campestris $\left(1.08 \mathrm{~g} \mathrm{~m}^{-2}\right)$ treated plots (Table 2).

The different ways of biomass incorporation showed significant variations in weed dry weight at 30 DAS and 50 DAS and for both the situation the control (no Brassica biomass incorporation) plots had the highest weed dry weight and $\mathrm{B}_{2}$ at 30 DAS and $\mathrm{B}_{5}$ at 50 DAS showed the lowest weed dry weight (Table 2). Cheema et al. (2008) reported that inclusion of allelopathic crops in rotation systems for weed suppression by early post-emergence application of the mixture of sorghum, sunflower, Brassica or mulberry water extracts suppressed total weed dry weight.

The interaction of Brassica species and ways of biomass incorporation showed significant variations of weed population in wheat field at 30 DAS and at 50 DAS (Table 3). The highest weed population (37.33 $\mathrm{m}^{-2}$ ) was recorded in $\mathrm{S}_{2} \mathrm{~B}_{1}$ plots at 30 DAS. The lowest weed population $\left(13.67 \mathrm{~m}^{-2}\right)$ was observed in $\mathrm{S}_{3} \mathrm{~B}_{4}$ at 30 DAS and in $\mathrm{S}_{1} \mathrm{~B}_{3}\left(8.67 \mathrm{~m}^{-2}\right)$ at 50 DAS. The lowest weed dry weight $\left(0.74 \mathrm{~g} \mathrm{~m}^{-2}\right)$ was found in $S_{3} B_{2}$ at 30 DAS and in $S_{1} B_{5}\left(0.51 \mathrm{~g} \mathrm{~m}^{-2}\right)$ at 50 DAS.

Table 2. Weed density and weight of wheat as affected by Brassica biomass and methods of incorporation

\begin{tabular}{l|cc|c|c}
\hline \multirow{2}{*}{ Treatments } & \multicolumn{2}{|c|}{ Weed density $\left(\mathrm{no.}^{-2}\right)$} & \multicolumn{2}{c}{ Weed dry weight $\left(\mathrm{g} \mathrm{m}^{-2}\right)$} \\
\cline { 2 - 5 } & 30 DAS & 50 DAS & 30 DAS & 50 DAS \\
\hline Brassica species: & 17.67 & 14.07 & 1.16 & 1.08 \\
$\quad S_{1}$ & 25.60 & 20.20 & 1.72 & 0.96 \\
$S_{2}$ & 22.47 & 18.80 & 1.16 & 1.44 \\
$S_{3}$ & NS & NS & 0.350 & 0.208 \\
LSD $_{(0.05)}$ & & & & \\
Incorporation methods: & & &
\end{tabular}


Biswas et al.

\begin{tabular}{rcccc}
\hline $\mathrm{B}_{1}$ & 26.78 & 17.78 & 1.49 & 1.66 \\
$\mathrm{~B}_{2}$ & 17.78 & 20.11 & 0.89 & 1.10 \\
$\mathrm{~B}_{3}$ & 26.89 & 20.89 & 1.59 & 1.31 \\
$\mathrm{~B}_{4}$ & 15.33 & 16.56 & 1.11 & 0.93 \\
$\mathrm{~B}_{5}$ & 22.78 & 13.11 & 1.65 & 0.80 \\
$\mathrm{LSD}_{(0.05)}$ & 9.390 & $\mathrm{NS}$ & 0.534 & 0.491 \\
\hline
\end{tabular}

$\mathrm{S}_{1}=$ B. campestris $\mathrm{S}_{2}=$ B. juncea $\mathrm{S}_{3}=$ B. napus; $\mathrm{B}_{1}=$ No biomass $\mathrm{B}_{2}=$ Spreading above ground

$\mathrm{B}_{3}=$ mixed with soil $\mathrm{B}_{4}=$ spreading in lines $\mathrm{B}_{5}=50 \%$ spreading $+50 \%$ mixed with soil

Table 3. Weed density and weight in wheat as affected by interaction of Brassica biomass and methods of incorporation

\begin{tabular}{|c|c|c|c|c|}
\hline \multirow[t]{2}{*}{ Treatments } & \multicolumn{2}{|c|}{ Weed density (no. $\mathrm{m}^{-2}$ ) } & \multicolumn{2}{|c|}{ Weed dry weight $\left(\mathrm{g} \mathrm{m}^{-2}\right)$} \\
\hline & 30 DAS & 50 DAS & 30 DAS & 50 DAS \\
\hline $\mathrm{S}_{1} \mathrm{~B}_{1}$ & 17.00 & 19.33 & 0.91 & 1.78 \\
\hline $\mathrm{S}_{1} \mathrm{~B}_{2}$ & 15.67 & 17.67 & 1.01 & 1.31 \\
\hline $\mathrm{S}_{1} \mathrm{~B}_{3}$ & 15.33 & 8.67 & 0.93 & 1.01 \\
\hline $\mathrm{S}_{1} \mathrm{~B}_{4}$ & 17.67 & 15.67 & 1.13 & 0.78 \\
\hline $\mathrm{S}_{1} \mathrm{~B}_{5}$ & 22.67 & 9.00 & 1.80 & 0.51 \\
\hline $\mathrm{S}_{2} \mathrm{~B}_{1}$ & 37.33 & 22.00 & 2.31 & 1.71 \\
\hline $\mathrm{S}_{2} \mathrm{~B}_{2}$ & 21.33 & 29.67 & 0.92 & 1.03 \\
\hline $\mathrm{S}_{2} \mathrm{~B}_{3}$ & 36.67 & 14.00 & 2.68 & 0.47 \\
\hline $\mathrm{S}_{2} \mathrm{~B}_{4}$ & 14.67 & 19.00 & 1.26 & 0.99 \\
\hline $\mathrm{S}_{2} \mathrm{~B}_{5}$ & 18.00 & 16.33 & 1.44 & 0.61 \\
\hline $\mathrm{S}_{3} \mathrm{~B}_{1}$ & 26.00 & 12.00 & 1.26 & 1.48 \\
\hline $\mathrm{S}_{3} \mathrm{~B}_{2}$ & 16.33 & 13.00 & 0.74 & 0.95 \\
\hline $\mathrm{S}_{3} \mathrm{~B}_{3}$ & 28.67 & 40.00 & 1.16 & 2.46 \\
\hline $\mathrm{S}_{3} \mathrm{~B}_{4}$ & 13.67 & 15.00 & 0.93 & 1.04 \\
\hline $\mathrm{S}_{3} \mathrm{~B}_{5}$ & 27.67 & 14.00 & 1.72 & 1.29 \\
\hline $\operatorname{LSD}_{(0.05)}$ & 16.325 & 22.252 & 0.925 & 0.845 \\
\hline
\end{tabular}

$\mathrm{S}_{1}=$ B. campestris $\mathrm{S}_{2}=$ B. juncea $\mathrm{S}_{3}=$ B. napus; $\mathrm{B}_{1}=$ No biomass $\mathrm{B}_{2}=$ Spreading above ground

$\mathrm{B}_{3}=$ mixed with soil $\mathrm{B}_{4}=$ spreading in lines $\mathrm{B}_{5}=50 \%$ spreading $+50 \%$ mixed with soil

\section{Wheat yield and other crop characters}

Incorporation of Brassica juncea biomass to the wheat field showed the maximum 1000-grain weight of wheat (42.13 g) that statistically similar to Brassica napus but the lowest grain weight in Brassica campestris biomass incorporation. Mansoor et al. (2004) stated that water extracts of sorghum, eucalyptus and acacia were significantly affected 1000-grain weight of mungbean. The highest harvest index (48.47\%) was given by Brassica campestris biomass incorporation that similar to Brassica juncea and the lowest in Brassica napus (Table 4).

Table 4. Effect of Brassica spp. and ways of biomass incorporation on yield and other crop characters of wheat

\begin{tabular}{l|c|c|c|c|c|c}
\hline Treatments & $\begin{array}{c}\text { Plant } \\
\text { height } \\
(\mathrm{cm})\end{array}$ & $\begin{array}{c}\text { Filled } \\
\text { grains } \\
\text { spike }^{-1} \\
(\text { no. })\end{array}$ & $\begin{array}{c}\text { 1000-grain } \\
\text { weight } \\
(\mathrm{g})\end{array}$ & $\begin{array}{c}\text { Grain yield } \\
\left(\mathrm{t} \mathrm{ha}^{-1}\right)\end{array}$ & $\begin{array}{c}\text { Straw yield } \\
\left(\mathrm{t} \mathrm{ha}^{-1}\right)\end{array}$ & $\begin{array}{c}\text { Harvest } \\
\text { index } \\
(\%)\end{array}$ \\
\hline
\end{tabular}




\begin{tabular}{ccccccc}
\hline Brassica species: & & & & & & \\
$\mathrm{S}_{1}$ & 84.15 & 41.32 & 37.07 & 3.43 & 3.64 & 48.47 \\
$\mathrm{~S}_{2}$ & 82.53 & 39.63 & 42.13 & 3.52 & 3.84 & 47.60 \\
$\mathrm{~S}_{3}$ & 84.19 & 45.12 & 40.38 & 3.32 & 3.73 & 47.27 \\
LSD $_{(0.05)}$ & $\mathrm{NS}$ & $\mathrm{NS}$ & 2.883 & $\mathrm{NS}$ & $\mathrm{NS}$ & 1.012 \\
Incorporation methods: & & & & & & \\
$\mathrm{B}_{1}$ & & & & & & \\
$\mathrm{~B}_{2}$ & 81.74 & 38.95 & 39.56 & 3.54 & 3.85 & 47.78 \\
$\mathrm{~B}_{3}$ & 86.08 & 43.08 & 40.84 & 3.46 & 3.76 & 48.11 \\
$\mathrm{~B}_{4}$ & 84.83 & 44.32 & 43.63 & 3.32 & 3.84 & 46.22 \\
$\mathrm{~B}_{5}$ & 79.96 & 40.62 & 37.18 & 3.37 & 3.66 & 47.78 \\
$\mathrm{LSD}_{(0.05)}$ & 85.50 & 43.16 & 38.30 & 3.43 & 3.56 & 49.00 \\
& 2.340 & 3.491 & 3.790 & $\mathrm{NS}$ & $\mathrm{NS}$ & 0.972 \\
\hline
\end{tabular}

$\mathrm{S}_{1}=$ B. campestris $\mathrm{S}_{2}=$ B. juncea $\mathrm{S}_{3}=$ B. napus; $\mathrm{B}_{1}=$ No biomass $\mathrm{B}_{2}=$ Spreading above ground $\mathrm{B}_{3}=$ mixed with soil $\mathrm{B}_{4}=$ spreading in lines $\mathrm{B}_{5}=50 \%$ spreading $+50 \%$ mixed with soil

The tallest plant $\left(86.08 \mathrm{~cm}\right.$ ) was recorded from $\mathrm{B}_{2}$ (spreading above ground) that similar to $\mathrm{B}_{5}$ and $\mathrm{B}_{3}$ but $\mathrm{B}_{4}$ produced the shortest plant height $(79.96 \mathrm{~cm})$. The maximum number of filled grains spike ${ }^{-1}(44.32)$ was recorded from $B_{3}$ (mixed with soil) that similar to $B_{5}$ (50\% spreading $+50 \%$ mixed with soil), $B_{2}$ (spreading above the ground) and $\mathrm{B}_{4}$ (spreading in line) while the minimum (38.95) was found in $\mathrm{B}_{1}$ (control) plot (Table 4). $\mathrm{B}_{3}$ treatment showed the highest 1000 -grain weight (43.63 g) that similar to $\mathrm{B}_{2}$ whereas $B_{4}$ gave the lowest grain weight (37.18 g) that similar to $B_{5}, B_{2}$ and $B_{1}$. The highest harvest index (49.00\%) was recorded from $\mathrm{B}_{5}$ that similar to $\mathrm{B}_{2}, \mathrm{~B}_{1}$ and $\mathrm{B}_{4}$ while the lowest $(46.22 \%)$ in $\mathrm{B}_{3}$.

The combined effect of Brassica species and different incorporation methods significantly effect the grain yield and other studied crop characters of wheat where $S_{2} B_{2}$ (Brassica juncea spreading above ground) showed the highest grain yield $\left(3.83 \mathrm{t} \mathrm{ha}^{-1}\right)$, straw yield $\left(4.17 \mathrm{t} \mathrm{ha}^{-1}\right)$, superior plant height $(85.90 \mathrm{~cm})$ and 1000 -grain weight (43.93 g) whereas the lowest grain yield (3.06 t ha-1) was found in $\mathrm{S}_{3} \mathrm{~B}_{2}($ Brassica napus spreading above ground). Baker and Bhowmik (2001) reported that application of imported residues was found more effective in yield enhancement of vegetable cropping systems. The $\mathrm{S}_{3} \mathrm{~B}_{5}$ (Brassica napus with $50 \%$ spreading $+50 \%$ mixed with soil) had the maximum number of filled grains spike $^{-1}$ (47.24) and the minimum (35.87) in $\mathrm{S}_{1} \mathrm{~B}_{4}$ (Table 5).

Table 5. Interaction effect of Brassica spp. and ways of biomass incorporation on yield and other crop characters of wheat

\begin{tabular}{l|c|c|c|c|c|c}
\hline Treatments & $\begin{array}{c}\text { Plant height } \\
(\mathrm{cm})\end{array}$ & $\begin{array}{c}\text { Filled grains } \\
\text { spike- } \\
(\text { no. })\end{array}$ & $\begin{array}{c}\text { 1000-grain } \\
\text { weight } \\
(\mathrm{g})\end{array}$ & $\begin{array}{c}\text { Grain } \\
\text { yield } \\
\left(\mathrm{t} \mathrm{ha}^{-1}\right)\end{array}$ & $\begin{array}{c}\text { Straw } \\
\text { yield } \\
\left(\mathrm{t} \mathrm{ha}^{-1}\right)\end{array}$ & $\begin{array}{c}\text { Harvest } \\
\text { index } \\
(\%)\end{array}$ \\
\hline
\end{tabular}


Biswas et al.

\begin{tabular}{ccccccc}
\hline $\mathrm{S}_{1} \mathrm{~B}_{1}$ & 83.20 & 38.91 & 38.65 & 3.61 & 3.44 & 51.00 \\
$\mathrm{~S}_{1} \mathrm{~B}_{2}$ & 83.00 & 44.67 & 34.97 & 3.50 & 3.72 & 48.67 \\
$\mathrm{~S}_{1} \mathrm{~B}_{3}$ & 88.00 & 46.40 & 39.81 & 3.39 & 3.95 & 46.00 \\
$\mathrm{~S}_{1} \mathrm{~B}_{4}$ & 81.13 & 35.87 & 33.09 & 3.39 & 3.64 & 48.00 \\
$\mathrm{~S}_{1} \mathrm{~B}_{5}$ & 85.40 & 40.73 & 38.49 & 3.28 & 3.44 & 48.67 \\
$\mathrm{~S}_{2} \mathrm{~B}_{1}$ & 79.80 & 36.07 & 40.72 & 3.33 & 3.83 & 46.33 \\
$\mathrm{~S}_{2} \mathrm{~B}_{2}$ & 85.90 & 37.51 & 43.93 & 3.83 & 4.17 & 47.67 \\
$\mathrm{~S}_{2} \mathrm{~B}_{3}$ & 84.67 & 43.15 & 48.77 & 3.33 & 3.89 & 46.00 \\
$\mathrm{~S}_{2} \mathrm{~B}_{4}$ & 79.60 & 39.76 & 39.40 & 3.34 & 3.69 & 47.33 \\
$\mathrm{~S}_{2} \mathrm{~B}_{5}$ & 83.07 & 40.88 & 37.11 & 3.75 & 3.61 & 51.67 \\
$\mathrm{~S}_{3} \mathrm{~B}_{1}$ & 82.63 & 41.24 & 38.67 & 3.67 & 4.27 & 46.00 \\
$\mathrm{~S}_{3} \mathrm{~B}_{2}$ & 89.33 & 46.19 & 42.35 & 3.06 & 3.40 & 48.00 \\
$\mathrm{~S}_{3} \mathrm{~B}_{3}$ & 81.83 & 42.58 & 42.02 & 3.23 & 3.70 & 46.67 \\
$\mathrm{~S}_{3} \mathrm{~B}_{4}$ & 79.13 & 46.03 & 38.52 & 3.38 & 3.66 & 48.00 \\
$\mathrm{~S}_{3} \mathrm{~B}_{5}$ & 88.03 & 46.69 & 38.43 & 3.28 & 3.61 & 47.67 \\
$\mathrm{LSD}_{(0.05)}$ & 4.156 & 6.047 & 6.564 & 0.612 & 0.733 & 1.684 \\
\hline
\end{tabular}

$\mathrm{S}_{1}=$ B. campestris $\mathrm{S}_{2}=$ B. juncea $\quad \mathrm{S}_{3}=$ B. napus; $\mathrm{B}_{1}=$ No biomass $\mathrm{B}_{2}=$ Spreading above ground

$\mathrm{B}_{3}=$ mixed with soil $\mathrm{B}_{4}=$ spreading in lines $\mathrm{B}_{5}=50 \%$ spreading $+50 \%$ mixed with soil

\section{Conclusion}

Irrespective of three studied species, Brassica crop has significant role to suppress weed in wheat field. The nature of weed suppression varied among the incorporation methods. The higher grain yield of wheat was found with the incorporation of Brassica juncea biomass as spreading above ground. It is necessary to isolate the allelochemical in Brassica for implementing such eco-friendly method of weed control.

\section{Acknowledgement}

The financial support of SAURES (Sher-e-Bangla Agricultural University Research System) to conduct the research is gratefully acknowledged.

\section{References}

Anonymous. 1993. Sweet potato plants vs. weeds. HortIdeas. January. p.8.

Baker, A. V. and P. C. Bhowmik. 2001. Weed control with crop residues in vegetable cropping systems. J. Crop Prod. 4: 163-183.

Boydston, R. 2008. The use of mustard cover crops in potato rotations. $5^{\text {th }}$ World Congress on Allelopathy. The Saratoga Hilton, Saratoga Springs, New York, USA from 21-25 September, 2008. p.58.

Boydston, R. and A. Hang. 1995. Rapeseed green manure crop suppresses weeds in potato. Weed Technol. 9: 669-675.

Cheema, Z. A., A. Khaliq and M. N. Mushtaq. 2008. Current allelopathic research in Pakistan-some implications. $5^{\text {th }}$ World Congress on Allelopathy. The Saratoga Hilton, Saratoga Springs, New York, USA from 21-25 September, 2008. p.83.

Krishnan, G., D. L. Holshouser and S. J. Nissen. 1998. Weed control in Soybean (Glycine max) with green manure crops. Weed Technol. 12: 97-102.

Mansoor, M., H. K. Ahmad, H. Khan and M. Yaqoob. 2004. Development of economical weed management strategies for mungbean (Vigna radiata L. Wilczek.). Pak. J. Weed Sci. Res. 10: 151-156. 
Allelopathic Effect of Brassica on Wheat

Peterson, R. F. 1965. Wheat. Interscience Publishers, Inc. New York. p.256.

Putnam, A. R., J. DeFrank and J. P. Barnes. 1983. Exploitation of allelopathy for weed control in annual and perennial cropping systems. J. Chem. Ecol. 9: 1001-1010.

Schilling, D. G., A. D. Worsham and D. A. Danehower. 1986. Influence of mulch, tillage, and diphenamid on weed control, yield, and quality in no-till flue-cured tobacco. Weed Sci. 34: 738-744.

Sheila, D. 1986. Update: Suppressing weeds with allelopathic mulches. The IPM Practitioner. April. pp.1-4.

Sullivan, P. 2003. Principles of Sustainable Weed Management for Croplands. ATTRA Publication \#IP039.

Turk, M. A. and A. R. M. Tawaha. 2002. Effect of sowing rates and weed control methods on winter wheat under Mediterranean environment. Pakistan J. Agron. 16: 461-464.

Uremis, I., M. Arslan, A. Uludag and M. K. Sangun. 2009. Allelopathic potentials of residues of 6 Brassica species on johnsongrass (Sorghum halepense L. Pers.). African Biotech. 8: 3497-3501.

Worsham, A. D. 1991. Allelopathic cover crops to reduce herbicide input. Proceedings of the Southern Weed Science Society. 44th Annual. Volume 44. pp.58-69.

Yenish, J. P. and A. D. Worsham. 1993. Replacing herbicides with herbage: potential use for cover crops in notillage. pp.37-42. In: P.K. Bollich, (ed.) Proceedings of the Southern Conservation Tillage Conference for Sustainable Agriculture. Monroe, LA. June 15-17. 
Biswas et al. 